\title{
DIAGNOSTIC AND TREATMENT RELATED FACTORS DETERMINING RED CELL TRANSFUSION AMONG SICK NEONATES
}

\author{
Mini Chellamma Viswanathan', Sajith Vilambil2, Kumari Krishnakumariamma Chakrapani Usha ${ }^{3}$ \\ ${ }_{1}^{1}$ Assistant Professor, Department of Transfusion Medicine, Government Medical College, Trivandrum, Kerala, India. \\ ${ }^{2}$ Associate Professor, Department of Transfusion Medicine, Government Medical College, Thrissur, Kerala, India. \\ 3Professor, Department of Transfusion Medicine, Sree Mookambika Institute of Medical Sciences, Kanyakumari, Tamilnadu, India.
}

\section{ABSTRACT}

\section{BACKGROUND}

Red blood cell transfusion in neonates can be affected by diagnosis and treatment. In this research we reasoned those factors. We wanted to evaluate diagnostic and treatment related factors determining red cell transfusion among sick neonates

\section{METHODS}

This was a case control study done on 300 neonates admitted to the Neonatal Intensive Care Unit (NICU) of Sri Avittom Thirunal Hospital (SATH), Government Medical College, Thiruvananthapuram for a period of one and a half years. Cases were sick neonates transfused with packed red cells. Diagnostic and treatment related characteristics known to be associated with anaemia of prematurity were recorded. It included total number of phlebotomies performed, approximate blood loss per each phlebotomy, use of other blood components, duration of mechanical ventilation, duration of oxygen supplementation, type of antibiotics given, duration of treatment, duration of hospital stay and outcome of the baby. All statistical data were analysed using SPSS software version 16.

\section{RESULTS}

This study was a case control study done in 300 neonates, cases $(n=150)$ and controls $(n=150)$. Mean number of phlebotomies in the case group was $9.5 \pm 2.6$ and in the control group was $4.5 \pm 2.2$ and was statistically significant. On analysis, $72.7 \%$ of case group and $27.3 \%$ of the control group required mechanical ventilation and was statistically significant. Among the transfused group, $97.3 \%$ required oxygen supplementation while only $64.7 \%$ in the control group required it and was statistically significant. Mean duration of oxygen supplementation in the transfused group was $10 \pm 5.7$ days and in the non-transfused control group was $5.4 \pm 6.4$ days and this was statistically significant. Inotropes were administered in $86 \%$ of the case group and in $58 \%$ of the control group and was significant. The mean duration of administration of inotropes in the study group was $6.5 \pm 4.1$ days and in the control group was $4.9 \pm 5$ days and was significant. Duration of hospital stay was significantly higher in the transfused group

\section{CONCLUSIONS}

Mean number of phlebotomies, requirement and duration of mechanical ventilation, mean duration of oxygen supplementation, administration of inotropes, mean duration of administration of inotropes and duration of hospital stay was significantly higher in the transfused group.

\section{KEY WORDS}

Red Blood Cell, Transfusion, Sick Neonate, Low Birth weight, Anaemia

HOW TO CITE THIS ARTICLE: Viswanathan MC, Vilambil S, Usha KKC. Diagnostic and treatment related factors determining red cell transfusion among sick neonates. J. Evolution Med. Dent. Sci. 2019;8(26):2065-2068, DOI: 10.14260/jemds/2019/455

\section{BACKGROUND}

Red blood cell transfusion provides immediate oxygen delivery to the tissues and is an effective and rapid intervention to treat anaemia and reduce morbidity. The majority of Neonatal Intensive Care Units (NICU) adopts transfusion guidelines based on clinical conditions, days of life, need of mechanical ventilation, oxygen support, haemoglobin and haematocrit levels. We reasoned that assessing risk factors and clinical conditions before the first transfusion will improve our ability to estimate the need for RBC transfusions of low birth weight (LBW) infants.

'Financial or Other Competing Interest': None.

Submission 14-05-2019, Peer Review 18-06-2019,

Acceptance 24-06-2019, Published 01-07-2019.

Corresponding Author:

Dr. Sajith Vilambil,

Associate Professor

Department of Transfusion Medicine,

Government Medical College, Thrissur, Kerala, India.

E-mail: drsajithmenon@gmail.com

DOI: $10.14260 /$ jemds $/ 2019 / 455$

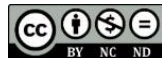

Such estimation can identify infants who require more number of RBC transfusions. Minimising the number of units of RBC transfusion will decrease donor exposure. Risk based estimation of blood usage can identify those infants who are likely to require only one/more transfusion. This helps to identify unnecessary transfusions also.

\section{METHODS}

This was a case control study done on 300 neonates. Sample population were newborn babies with gestational age less than 37 weeks and/or birth weight less than 2500 grams admitted to the Neonatal Intensive Care Unit (NICU) of Sri Avittom Thirunal Hospital (SATH), Government Medical College, Thiruvananthapuram.

SATH has a level III NICU caring for both inborn and out born infants. Study was done for a period of one and a half years in the Department of Transfusion Medicine, Government Medical College Thiruvananthapuram.

Cases are sick neonates admitted to the NICU who are transfused with packed red cells at least once during their hospital stay. Controls are sick neonates who did not receive 
packed cells. Infants with chromosomal abnormalities, congenital heart disease, other life-threatening congenital abnormalities, death within first 24 hours were excluded from the study.

Case records of sick neonates admitted in NICU of SATH for a period of one and a half years were studied. Diagnostic and treatment related characteristics known to be associated with anaemia of prematurity were recorded.

It included total number of phlebotomies performed, approximate blood loss per each phlebotomy, use of other blood components, duration of mechanical ventilation, duration of oxygen supplementation, type of antibiotics given, duration of treatment, duration of hospital stay and outcome of the baby.

\section{Ethics}

The parents of the study subjects were counselled about the nature of the study. A written consent was obtained from the parents of the newborns included in the study. The study was approved by the human ethical committee, Government Medical College Thiruvananthapuram.

\section{Statistics}

All statistical data were analysed using SPSS software version 16. Continuous variables were expressed as mean +/standard deviation. And qualitative data expressed as percentage. Independent $t$ test was used for comparing quantitative data between two groups. Categorical variables were compared using $\chi^{2}$ test. The predictive variables were calculated by univariate analysis.

\section{RESULTS}

Our study was a case control study done in 300 neonates admitted in the NICU of Sri Avittom Thirunal Hospital, Government Medical College, Thiruvananthapuram. Study subjects were divided into cases $(\mathrm{n}=150)$ and controls $(n=150)$. Diagnostic and treatment related characteristics were studied and analysed.

Mean number of phlebotomies in the case group was $9.5 \pm$ 2.6 and in the control group was $4.5 \pm 2.2$. The $p$ value 0.000 was statistically significant.

On analysis, $72.7 \%$ of case group and $27.3 \%$ of the control group required mechanical ventilation. The $\mathrm{p}$ value 0.000 was statistically significant. On assessment, $19.3 \%$ in the case group underwent mechanical ventilation for 1-4 days, $57.8 \%$ for $2-5$ days and $22.9 \%$ for more than 10 days. In the control group, $34.9 \%$ underwent mechanical ventilation for $1-4$ days, $44.2 \%$ for $2-5$ days and $20.9 \%$ for more than 10 days. The $p$ value 0.000 was statistically significant.

Among the transfused group, $97.3 \%$ required oxygen supplementation while only $64.7 \%$ in the control group required it. The $\mathrm{p}$ value 0.000 was statistically significant.

Among the transfused group, 97.3\% required oxygen supplementation while only $64.7 \%$ in the control group required it. The $\mathrm{p}$ value 0.000 was statistically significant.

On comparing the duration of oxygen supplementation, $21.2 \%$ of the case group required oxygen supplementation for 1-5 days, $45.2 \%$ of the case group required 6-10 days, $19.2 \%$ for $11-15$ days, $14.4 \%$ for more than 15 days. The mean requirement of oxygen supplementation was more in the case group.

\begin{tabular}{|c|c|c|c|c|c|}
\hline Group & Mean & SD & N & t & p \\
\hline Case & 9.5 & 2.6 & 150 & \multirow{2}{*}{$17.97^{* *}$} & \multirow{2}{*}{0.000} \\
\hline Control & 4.5 & 2.2 & 150 & & \\
\hline \multicolumn{7}{|c|}{ Table 1. Comparison of Number of Phlebotomies } \\
\hline
\end{tabular}

\begin{tabular}{|c|c|c|c|c|c|c|}
\hline Duration of & \multicolumn{2}{|c|}{ Case } & \multicolumn{2}{c|}{ Control } & \multirow{2}{*}{$\chi^{2}$} & \multirow{2}{*}{$\mathbf{p}$} \\
\cline { 2 - 5 } $\begin{array}{l}\text { Mechanical } \\
\text { Ventilation }\end{array}$ & Number & Percent & Number & Percent & & \\
\hline No & 41 & 27.3 & 107 & 71.3 & \multirow{2}{*}{$58.09^{* *}$} & 0.000 \\
\hline Yes & 109 & 72.7 & 43 & 28.7 & \\
\hline
\end{tabular}

Table 2. Comparison of Usage of Mechanical Ventilation

\begin{tabular}{|c|c|c|c|c|}
\hline \multirow{2}{*}{$\begin{array}{c}\text { Duration of } \\
\text { Mechanical } \\
\text { Ventilation in Days }\end{array}$} & \multicolumn{2}{|c|}{ Case } & \multicolumn{2}{c|}{ Control } \\
\cline { 2 - 5 } & Number & Percent & Number & Percent \\
\hline $1-4$ & 21 & 19.3 & 15 & 34.9 \\
\hline $2-5$ & 63 & 57.8 & 19 & 44.2 \\
\hline$>=10$ & 25 & 22.9 & 9 & 20.9 \\
\hline Mean \pm SD & \multicolumn{2}{|c|}{$5.2 \pm 4.8$} & \multicolumn{2}{c|}{$1.9 \pm 3.8$} \\
\hline
\end{tabular}

Table 3. Comparison of Mean Duration of Mechanical Ventilation $\mathrm{t}=6.47^{* *}, \mathrm{p}=0.000$

\begin{tabular}{|c|c|c|c|c|}
\hline \multirow{2}{*}{$\begin{array}{c}\text { Duration of } \\
\text { Mechanical } \\
\text { Ventilation in Days }\end{array}$} & \multicolumn{2}{|c|}{ Case } & \multicolumn{2}{c|}{ Control } \\
\cline { 2 - 5 } & Number & Percent & Number & Percent \\
\hline $1-4$ & 21 & 19.3 & 15 & 34.9 \\
\hline $2-5$ & 63 & 57.8 & 19 & 44.2 \\
\hline$>=10$ & 25 & 22.9 & 9 & 20.9 \\
\hline
\end{tabular}

Table 4. Comparison of Mean Duration of Mechanical Ventilation

\begin{tabular}{|c|c|c|c|c|c|c|}
\hline \multirow{2}{*}{$\begin{array}{c}\text { Supplementation } \\
\text { of Oxygen }\end{array}$} & \multicolumn{2}{|c|}{ Case } & \multicolumn{2}{c|}{ Control } & \multirow{2}{*}{ (2) } & \multirow{2}{*}{} \\
\cline { 2 - 5 } & Number & $\%$ & Number & $\%$ & & \\
\hline No & 4 & 2.7 & 53 & 35.3 & \multirow{2}{*}{$52^{* *}$} & \multirow{2}{*}{0.000} \\
\hline Yes & 146 & 97.3 & 97 & 64.7 & & \\
\hline
\end{tabular}

\begin{tabular}{|c|c|c|c|c|}
\hline Duration of Oxygen & \multicolumn{2}{|c|}{ Case } & \multicolumn{2}{c|}{ Control } \\
\cline { 2 - 5 } Supplement in Days & Number & Percent & Number & Percent \\
\hline $1-5$ & 31 & 21.2 & 53 & 54.6 \\
\hline $6-10$ & 66 & 45.2 & 21 & 21.6 \\
\hline $11-15$ & 28 & 19.2 & 10 & 10.3 \\
\hline$>15$ & 21 & 14.4 & 13 & 13.4 \\
\hline \multicolumn{3}{|c}{ Table 6. Comparison of Duration of Oxygen Supplement } \\
\hline
\end{tabular}

\begin{tabular}{|c|c|c|c|c|c|c|c|}
\hline \multirow{2}{*}{\multicolumn{2}{|c|}{$\begin{array}{l}\text { Duration of Oxygen } \\
\text { Supplement in Days }\end{array}$}} & \multicolumn{2}{|c|}{ Case } & \multicolumn{4}{|c|}{ Control } \\
\hline & & Count & Percent & \multicolumn{2}{|c|}{ Count } & \multicolumn{2}{|c|}{ Percent } \\
\hline \multicolumn{2}{|l|}{$1-5$} & 31 & 21.2 & \multicolumn{2}{|c|}{53} & \multicolumn{2}{|c|}{54.6} \\
\hline \multicolumn{2}{|l|}{$6-10$} & 66 & 45.2 & \multicolumn{2}{|c|}{21} & \multicolumn{2}{|c|}{21.6} \\
\hline \multicolumn{2}{|l|}{$11-15$} & 28 & 19.2 & \multicolumn{2}{|c|}{10} & \multicolumn{2}{|c|}{10.3} \\
\hline \multicolumn{2}{|l|}{$>15$} & 21 & 14.4 & 13 & & & 3.4 \\
\hline \multicolumn{2}{|l|}{ Mean \pm SD } & \multicolumn{2}{|c|}{$10 \pm 5.7$} & \multicolumn{4}{|c|}{$5.4 \pm 6.4$} \\
\hline \multicolumn{8}{|c|}{$\begin{array}{c}\text { Table } 7 \text { Comparison of Duration of Oxygen Supplementation } \\
\text { Based on Group }\end{array}$} \\
\hline \multicolumn{8}{|c|}{$\mathrm{t}=66.66^{* *}, \mathrm{p}=0.000$} \\
\hline \multirow{2}{*}{\begin{tabular}{|c|} 
Administration \\
of Inotropes
\end{tabular}} & \multicolumn{2}{|c|}{ Case } & \multicolumn{2}{|c|}{ Control } & \multirow{2}{*}{\multicolumn{2}{|c|}{$\chi^{2}$}} & \multirow{2}{*}{$\mathbf{p}$} \\
\hline & Number & Percent & Number & Percent & & & \\
\hline No & 21 & 14.0 & 63 & 42.0 & \multirow{2}{*}{\multicolumn{2}{|c|}{$29.17^{* *}$}} & \multirow{2}{*}{0.000} \\
\hline Yes & 129 & 86.0 & 87 & 58.0 & & & \\
\hline \multicolumn{8}{|c|}{ Table 8. Comparison of Administration of Inotropes } \\
\hline
\end{tabular}

\begin{tabular}{|c|c|c|c|c|}
\hline $\begin{array}{c}\text { Duration of } \\
\text { Administration of } \\
\text { Inotropes (Days) }\end{array}$ & \multicolumn{2}{|c|}{ Case } & \multicolumn{2}{c|}{ Control } \\
\cline { 2 - 5 } & Number & Percent & Number & Percent \\
\hline $1-5$ & 50 & 38.8 & 32 & 36.8 \\
\hline $6-10$ & 62 & 48.1 & 29 & 33.3 \\
\hline$>10$ & 17 & 13.2 & 26 & 29.9 \\
\hline Mean \pm SD & \multicolumn{2}{|c|}{$6.5 \pm 4.1$} & \multicolumn{2}{c|}{$4.9 \pm 5$} \\
\hline Table 9. Comparison of Duration of Administration of Inotropes \\
\hline \multicolumn{3}{|c}{$\mathrm{t}=3.16^{* *}, \mathrm{p}=0.002$} \\
\hline
\end{tabular}




\begin{tabular}{|c|c|c|c|c|}
\hline Duration of Hospital & \multicolumn{2}{|c|}{ Case } & \multicolumn{2}{c|}{ Control } \\
\cline { 2 - 5 } Stay in Days & Number & Percent & Number & Percent \\
\hline$<7$ & 34 & 22.7 & 122 & 81.3 \\
\hline $8-14$ & 39 & 26.0 & 28 & 18.7 \\
\hline$>=15$ & 77 & 51.3 & 0 & 0.0 \\
\hline Mean \pm SD & \multicolumn{2}{|c|}{$15 \pm 8.3$} & \multicolumn{2}{c|}{$4.9 \pm 2.4$} \\
\hline Table 10. Comparison of Duration of Hospital Stay in Days \\
\hline
\end{tabular}

Mean duration of oxygen supplementation in the transfused group was $10 \pm 5.7$ days and in the non-transfused control group was $5.4 \pm 6.4$ days. This was statistically significant.

While comparison of administration of inotropes was done, inotropes were administered in $86 \%$ of the case group and in $58 \%$ of the control group. The p value was significant. The mean duration of administration of inotropes in the study group was $6.5 \pm 4.1$ days and in the control group was $4.9 \pm 5$ days. $p$ value was significant.

On analysis, $51.3 \%$ of the case group required hospital stay for more than 15 days, $26 \%$ for $8-14$ days and $22.7 \%$ for less than 7 days. But in the control group, no neonates required hospital stay for more than 15 days, only $18.7 \%$ for 8-14 days and $81.3 \%$ for less than 7 days. Duration of hospital stay was significantly higher in the transfused group. No deaths reported in the case and control groups.

\section{DISCUSSION}

In our study, neonates who had received transfusions were included in the case group and those who had not received transfusions were included in the control group. Our study compared the demographic characteristics and variables which are known to be associated with transfusion of packed red cells in neonates.

Since phlebotomy losses constitute an important cause of anaemia of prematurity, ${ }^{1-4}$ we compared the number of phlebotomies in the two groups. Iatrogenic anaemia was significantly higher in the transfused group. Mean number of phlebotomies in the transfused group was $9.5 \pm 2.6$. This result correlated with several studies. ${ }^{5-9} \mathrm{~A}$ multicentre study published by Miyashiro and co-workers found that each 10 $\mathrm{ml} / \mathrm{kg}$ of blood loss increases the number of transfusions by $27 \%{ }^{6}$

In our study, $72.7 \%$ of the neonates of the case group received mechanical ventilation compared to $28.7 \%$ in the control group. Mean duration of mechanical ventilation in the case group was $5.2 \pm 4.8$ days. This value is significantly higher compared to that of control group. Our results were similar to previous studies. 10,11 In our study, $97 \%$ neonates in the transfused group required oxygen supplementation compared to only $64 \%$ in the non-transfused group. It was seen that the transfused group had a mean duration of oxygen usage of $10 \pm 5.7$ days compared to $5.4 \pm 6.4$ days in the control group. Our data agreed with many previous studies. ${ }^{11}$

Regarding administration of inotropes, it was seen that $86 \%$ of the transfused group required inotropes compared to only $58 \%$ in the control group. Mean duration of usage of inotropes in the case group was $6.5 \pm 4.1$ and $4.9 \pm 5$ in the control group. These findings are of great significance in our studies and it agrees with other studies. Several authors showed that variables such as gestational age, birth weight, phlebotomy losses, days on mechanical ventilation, length of hospital stay etc. were associated with the number of RBC transfusions in preterm infants.9,11 In our study, we obtained similar results regarding most of such variables.

The need for RBC transfusions in LBW infants had decreased a lot over the past two decades due to reduction in phlebotomy blood losses, adoption of more restrictive transfusion guidelines and to a lesser extent, the use of recombinant erythropoietin (EPO).12,13 Meyer studied LBW infants submitted to restrictive guidelines for $\mathrm{RBC}$ transfusions and found a reduction in the number of transfusions without threatening their clinical outcome. ${ }^{14}$

Currently, there are no standard guidelines for deciding transfusions in Neonatal Intensive Care Units (NICUs). Protocols may exist in individual units but there is no uniformity. Most transfusion protocols are related to respiratory functioning of neonates. ${ }^{15}$ Values in our study point to the fact that the variables like 5 minutes APGAR score, duration of oxygen supplementation, duration of mechanical ventilation had association with transfusion requirements. Conservative approach to reduce transfusion requirements by accepting lower haematocrit values is the recent trend. ${ }^{16}$ In our study also, the lower pre transfusion haematocrit had significant association with transfusion requirements.

The variability of practices in critical care setting was demonstrated by a survey administered to Canadian, French, Belgian and Swiss paediatric intensivists regarding transfusion practices in a tertiary care paediatric setting. The Haemoglobin transfusion trigger was 7-13 g/dl for the majority of scenarios. ${ }^{17}$ Armano, Gauvin and co-workers concluded in a study that a significant proportion of critically ill children receive at least one RBC transfusion during their NICU stay. 18

Goodman A. M, Murray P. M and their co-workers conducted a retrospective cohort study based on variables like mean initial haemoglobin levels of $7.4 \pm 1.4 \mathrm{gm} / \mathrm{dl}$, where the number of days of oxygen use, mechanical ventilation, vasoactive agents used, length of stay in NICU etc., and found that mortality in the transfused group was $6.9 \%$ versus $0.9 \%$ in the non-transfused group. In a multicentre prospective cohort study, Dos Santos and co-workers noticed that infants who had received at least one RBC transfusion compared to the non-transfused were of low gestational age, low birth weight, low first and five minutes APGAR score. 12

Fabres et al. found that $85 \%$ of preterm received red blood cell transfusion and it was associated with the use of inotropic drugs. ${ }^{19}$ Mimica et al. found that number of transfusions was associated with phlebotomy blood loss, duration of mechanical ventilation, peri-intraventricular haemorrhage and use of liberal RBC transfusion guidelines.

Amelia et al found out that patient with higher SNAPPE II score had higher likelihood of being transfused. Kling et al. described a prediction model for transfusion in preterm neonates based on phlebotomy blood loss and clinical severity score. ${ }^{20}$ In a multicentre study the relative risk of hospital death was greater among those who received RBC transfusion in first 28 days of life. The risk of death after was greater who received three or more RBC transfusions. ${ }^{21}$

The use of umbilical catheter was associated with a greater frequency of RBC transfusions. The use of supplementary oxygen, mechanical ventilation and vasoactive drugs were also associated with the indication for 
transfusions possibly due to the need for support to improve oxygenation and/or tissue perfusion. In a study by Guillén et al. they found that the need for supplementary oxygen, need for respiratory support, postnatal age, number of reticulocytes and the use of inotropic drugs had influence on the decision to RBC transfusions. 22

A reduction in phlebotomy blood loss is recognized as the most effective measure for diminishing the need for RBC transfusions. Madan et al. showed a $46 \%$ reduction in the number of transfusions in extremely-low-birthweight preterm infants using a bedside blood gas analyser, which reduced the volume of blood for laboratory exams. ${ }^{23}$ Mahieu et al. found a reduction in the percentage of premature newborns that received transfusions after adopting of a multi-parameter monitor for laboratory analyses. ${ }^{24}$

\section{CONCLUSIONS}

Mean number of phlebotomies, requirement and duration of mechanical ventilation, mean duration of oxygen supplementation, administration of inotropes, mean duration of administration of inotropes and duration of hospital stay were significantly higher in the transfused group.

\section{ACKNOWLEDGEMENT}

We offer our sincerest obligation to Dr. K. C. Usha, Professor and HOD, Department of Transfusion Medicine, Sree Mookambika Institute of Medical Sciences, Kulasekharam, Kanyakumari, Tamilnadu and Dr Lalitha Kailas Professor and HOD in Dept. of Paediatrics, Gokulam Medical College, Trivandrum, and Dr. Shobha Kumar, Professor in Dept. of Paediatrics, Govt. Medical College Trivandrum, for their scholarly guidance in the course of this work.

\section{REFERENCES}

[1] Nexo E, Christenson NC, Olesen J. Volume of blood removed for analytical purposes during hospital stay of LBW infants. Clin Chem 1981;27:759-61.

[2] Obladen M, Sachsenwegar M, Stahnke M. Blood sampling in very low birth weight infants receiving different levels of intensive care. Eur J Pediatr 1988;147(4):399-404.

[3] Ringer SA, Richardson DK, Sacher RA, et al. Variations in transfusion practice in neonatal intensive care. Pediatrics 1998;101(2):194-200.

[4] Madsen LP, Rasmoosen MK, Bjerrehaard LL, et al. Impact of blood sampling in very preterm infants. Scand J Clin Lab Invest 2000;60(2):125-32.

[5] Franz AR, Pohlandt F. RBC transfusions in very and extremely low birth weight infants under restrictive transfusion guidelines: is exogenous EPO necessary? Arch Dis Child Foetal Neonatal Ed 2001;84(2):F96F100.

[6] Cook S, Gunter J, Wissel M. Effective use of a strategy using assigned RBC units to limit donor exposure for neonatal patients; transfusion 1993;33(5):379-83.

[7] Mimica AF, Dos Santos AM, Da Cunha DH, et al. A very strict guideline reduces the number of $\mathrm{RBC}$ tranfusions in preterm infants. Vox Sang 2008;95(2):106-11.

[8] Venancio JP, Dos Santos AMM, Guinsburg R, et al. Strict guideline reduces the need for RBC transfusions in premature infants. J Trop Peditri 2007;53(2):78-82.
[9] Franz AR, Pohlandt F. RBC transfusion in very low birth weight Infants under restrictive guidelines: is exogenous erythropoietin necessary? Arch Dis Child Fetal Neonatal Ed 2001;84(2):F96-F100.

[10] Dos Santos AM, Guinsburg R, Procianoy RS, et al. Variability on red blood cell transfusion practices among Brazilian neonatal intensive care units. Transfus 2010;50(1):150-9.

[11] Paul DA, Pearlman SA, Leef KH, et al. Predicting RBC transfusion in very low birth weight infants based on clinical risk factors. Thomas Jefferson University. Del Med J 1997;69(11):555-61.

[12] Malek A, Sager R, Eckardt KU, et al. Lack of transport of EPO across human placenta as studied by an in vitro perfusion system. Pflugers Arch 1994;427(1-2):15761.

[13] Strauss RG. Controversies in the management of anaemia of prematurity using single donor RBC transfusions and/or recombinant human EPO. Transfus Med Rev 2006;20(1):34-44.

[14] Widness JA, Susa JB, Garcia JF, et al. Increased erythropoiesis and elevated EPO in infants born to diabetic mothers and hyperinsulinaemic rhesus fetuses. J Clin Invest 1981;67(3):637-42.

[15] Bifano EM, Smith F, Borer J. Relationship between determinants of oxygen delivery and respiratory abnormalities in preterm infants with anaemia. J Paeditrics 2002: p. 192-223.

[16] Alverson DC. The physiologic impact of anaemia in neonates. Clin Perinatology 1995;22(3):609-25.

[17] Laverdiere C, Gauvin F, Herbert PC, et al. Survey on transfusion practices of paediatric intensivists. Pediatr Critical Care Med 2002;3(4):335-40.

[18] Horbar JD, Badger GJ, Carpenter GH, et al. Trends in mortality and morbidity for very low birth weight infants, 1991-1999. Paediatrics 2002;110(1 Pt 1):14351.

[19] Fabres J, Wehrli G, Marques MB, et al. Estimating blood needs for very-low-birth-weight infants. Transfusion 2006;46(11):1915-20.

[20] Kling PJ, Sullivan TM, Leftwich ME, et al. Score for neonatal acute physiology and phlebotomy blood loss predict erythrocyte transfusions in premature infants. Arch Pediatr Adolesc Med 1997;151(1):27-31.

[21] Dos Santos AM, Guinsburg R, De Almeida MF, et al. Red blood cell transfusions are independently associated with intra-hospital mortality in very low birth weight preterm infants. J Pediatr 2011;159(3):371-6.e1-3.

[22] Guillen U, Cummings JJ, Bell EF, et al. International survey of transfusion practices for extremely premature infants. Semin Perinatol 2012;36(4):244-7.

[23] Madan A, Kumar R, Adams MM, et al. Reduction in red blood cell transfusions using a bedside analyzer in extremely low birth weight infants. J Perinatol 2005;25(1):21-5.

[24] Mahieu L, Marien A, De Dooy J, et al. Implementation of a multi-parameter Point-of-Care-blood test analyzer reduces central laboratory testing and need for blood transfusions in very low birth weight infants. Clin Chim Acta 2012;413(1-2):325-30. 